\title{
FutureJournal
}

\section{TRATEGIC MANAGEMENT IN PUBLIC ADMINISTRATION: A BALANCED SCORECARD APPLICABILITY FRAMEWORK IN SCHOOL MANAGEMENT}

\author{
1 Pedro Henrique de Oliveira \\ 2 Marco Antonio Catussi Paschoalotto \\ 3 Diego Valério de Godoy Delmônico \\ 4 Fernando de Souza Coelho \\ 5 Fernando César Almada Santos \\ 6 Edmundo Escrivão Filho
}

\begin{abstract}
Purpose - This study aims at developing a framework of the Balanced Scorecard (BSC) in public educational organizations.

Theoretical framework - There are 3-sections: Strategic planning in public sector, Balanced Scorecard and BSC in the public sector. Strategic management in public administration is an important issue, with the BSC as one of the most widely used tools. Although, the application of this technique in public schools is still unexplored and uncommon, it does possess the potential to improve their effectiveness.
\end{abstract}

Methodology - A 3-stage qualitative approach: (i) 8 semi-structured interviews with the principals of participating schools; (ii) 4 stages of focus groups with 3 of the principals from different schools; and (iii) non-participant observation using a field diary. Also, the data were analyzed through content analysis and cross-referencing the different forms of data collected.

Findings - The results do not indicate a vast knowledge concerning the BSC's techniques and tools, or an alignment between management planning posture, principles nor objectives of BSC application. Also, school planning is realized through the expertise of the Principal, without instruments of strategic management. Finally, adapted BSC models and strategic maps were proposed in public schools to collaborate and facilitate the strategic management process.

Research, Practical \& Social implications - The paper contributes towards developing new research agendas for strategic management in Brazil, with the possibility of improving public results and to appoint new practices in public schools.

Originality/value - We have collaborated with the creation of a tool to use in the strategic planning of primary schools and pushing BSC studies into public sectors.

Keywords: Strategic management. Balanced scorecard. Strategic Map. Public administration. Public school.

\section{How to cite the article:}

Oliveira, P., Paschoalotto, M., Delmônico, D., Coelho, F., Santos, F., \& Escrivão Filho, E. (2020). Strategic Management in Public Administration: A Balanced Scorecard Applicability Framework in School Management. Future Studies Research Journal: Trends and Strategies, 12(3), 458-482. doi:https://doi.org/10.24023/FutureJournal/2175-5825/2020.v12i3.517

\footnotetext{
${ }^{1}$ School of Engineering, University of São Paulo - EESC/USP, São Paulo, (Brasil). E-mail: oliveira.pedro@usp.br Orcid id: https://orcid.org/0000-0002-1616-6465

${ }^{2}$ University of West Paulista - UNOESTE, São Paulo, (Brasil). E-mail: marcocatussi@unoeste.br Orcid id: https://orcid.org/0000-0003-2276-8531

33auru Engineering School, Paulista State University - FEB/UNESP, São Paulo, (Brasil). E-mail: diegodelmonico@ gmail.com Orcid id: https://orcid.org/0000-0001-5268-190X

4 School of Arts, Sciences and Humanities, University of São Paulo - EACH/USP, São Paulo, (Brasil). E-mail: fernandocoelho@usp.br Orcid id: https://orcid.org/0000-0003-2803-0722

${ }^{5}$ School of Engineering, University of São Paulo - EESC/USP, São Paulo, (Brasil). E-mail: almada@sc.usp.br Orcid id: http://orcid.org/0000-0002-9317-088X

${ }^{6}$ School of Engineering, University of São Paulo - EESC/USP, São Paulo, (Brasil). E-mail: edesfi@sc.usp.br Orcid id: http://orcid.org/0000-0001-5181-5398
} 


\section{ESTÃO ESTRATÉGICA NO SETOR PÚBLICO: A APLICAÇÃO DE UM ESBOÇO TEÓRICO DO BALANCED SCORECARD NA GESTÃO ESCOLAR}

\section{Resumo}

Objetivo - O objetivo foi desenvolver um esboço teórico do Balanced Scorecard (BSC) em organizações públicas escolares.

Quadro teórico - Há 3 seções: Planejamento estratégico no setor público, Balanced Scorecard e BSC no setor público. A gestão estratégica na administração pública é um tópico importante, com o BSC sendo muito utilizado. Entretanto, a aplicação desse instrumento em escolas públicas ainda é pouco explorada e pode aumentar a sua efetividade.

Metodologia - Houve 3 etapas utilizando-se a abordagem qualitativa. (i) 8 entrevistas semiestruturadas com diretoras escolares; (ii) 4 dias de grupo focal com 3 diretoras e; e (iii) observação não participante com diário de campo. Os dados também foram analisados por meio da análise de conteúdo e triangulados pelas diversas coletas de dados.

Resultados - Os resultados indicam que não há conhecimento das técnicas e ferramentas do BSC e que poderia haver um alinhamento do planejamento estratégico pela aplicação do BSC. Observou-se também que o planejamento escolar é feito pela experiência da diretora, sem uso de instrumentos de gestão estratégica. Por fim, foi proposto um esboço teórico da adaptação do BSC e mapa estratégico, contribuindo para o processo da gestão estratégica.

Contribuições práticas, sociais e de pesquisa - $O$ artigo contribuiu para 0 desenvolvimento de uma nova agenda de pesquisa na gestão estratégica brasileira, a possibilidade de melhoria no setor público e o apontamento de novas práticas em escolas públicas.

Originalidade/relevância - Foram criados instrumentos que podem ser usados na gestão estratégica das escolas públicas. Também pelo avanço do uso do BSC no setor público.

Palavras-chave: Gestão estratégica. Balanced Scorecard. Mapa estratégico. Administração pública. Escola pública.

\section{Como Citar:}

Oliveira, P., Paschoalotto, M., Delmônico, D., Coelho, F., Santos, F., \& Escrivão Filho, E. (2020). Gestão Estratégica no Setor Público: A Aplicação de um Esboço Teórico do Balanced Scorecard na Gestão Escolar. Future Studies Research Journal: Trends and Strategies [FSRJ], 12(3), 458-482. doi:https://doi.org/10.24023/FutureJournal/2175-5825/2020.v12i3.517 


\section{INTRODUCTION}

Although attention from the scientific community toward strategic planning has dwindled since 1990, it is still one of the most widely used tools in contemporary management (Wolf \& Floyd, 2017). Also, articles on this subject are still being published by relevant scientific journals (Najgebauer, Antkiewicz, Pierzchała \& Rulka, 2017), including journals outside the scope of management, in areas such biology (Ringma, Wintle, Fuller, Fisher, Bode, 2017) and engineering (Purnawan \& Sanjaya, 2017).

This does not go without criticism, as the literature suggests that issues concerning strategic planning in the public sector should be more dynamic and integrative (Mintzberg, 1994; Olsen, 2012). Despite such, recent literature has recognized the positive aspects of strategic planning in the public sector (George, 2017).

The Balanced Scorecard (BSC) is a system widely used for deploying strategic management (Queiroz \& Lobosco, 2015). One tool for the development of BSC is strategic map, which also aids in the strategic management process by showing the visual framework for the objectives of the cited perspectives (Kaplan \& Norton, 2000).

There are studies on the application of BSC in the public sector, which include a variety of contexts - Italian (Bracci, Maran \& Inglis, 2017), Czech Republic (Plaček, Půček \& Šilhánková, 2017), Ethiopia (Bobe, Mihret \& Obo, 2017) and New Zealand (Northcott \& Taulapapa, 2012; Greatbanks \& Tapp, 2007). However, few studies present Brazilian cases, especially when it comes to observing education management.

Critical studies based on the use of BSC for public sector organizations suggest the need for community participation in strategic management and the proper understanding of the internal-external environment (Maccarone, Filiciotto, Buffa, Mazzola \& Buscaino, 2014; Rahiminia \& Karzogar, 2016; Souza \& Cordeiro, 2010; Younis \& Knight, 2014). Despite this criticism, BSC contributes toward improving the performance of public sector organizations (Kaplan \& Bower, 1999). The study by Northcott and Taulapapa (2012), for example, shows the BSC being used for supporting performance management in public sector organizations.

On the other hand, the administration of school organizations is one management activity of the public sector. This function is responsible for pedagogical organization of school activities by aligning educational issues with strategic vision and intertwined actions (Lück, 2009). In this process, the political perspectives of the principal and teachers (Paro, 2010) coexist alongside the management approach (Lunenberg, 2010).

Despite the relevance concerning the matter, there are significant research gaps in the public sector in terms of the BSC regarding strategic planning in educational organizations. Additionally, no papers were found that aim at developing a theoretical model for a better understanding into BSC, and this is also true when seen from the Brazilian context. 
In order to cover this gap, this study sought to answer the following question: what is the theoretical structure that best integrates the perspectives of school administration with strategic management, involving BSC and strategic mapping, in the public sector? To answer this question, this paper shows the development of a framework that synthesizes the application of the Balanced Scorecard in public educational organizations. This framework was developed based on multiple case studies and multiple methods of data collection such as interviews, questionnaires, focus group, non-participant observation and field diary with public administration school organizations.

The theoretical contributions of this paper include the development of a framework for strategic management by using empirical data from public school organizations and a theoretical model for BSC implementation in public sector educational organizations. This study potentially contributes to researchers, where it allows for more confirmatory and comparative approaches. In addition, this paper provides an empirical basis that will allow for some anticipation of challenges concerning BSC implementation in public schools and organizations.

\section{THEROTICAL BACKGROUND}

\subsection{STRATEGIC PLANNING IN THE PUBLIC SECTOR}

Strategic management in the public sector has its emphasis placed on strategic planning, as in other areas. However, other stages of the strategic cycle, such as execution and evaluation, were neglected and these have an influence over possible strategy failures (Mintzberg, Lampel \& Ahlstrand, 1999; Thompson Jr. \& Strickland III, 2000).

Strategic planning in the public sector is essential not only in the present, but also for the future (Poister, 2010). According to the study by George (2017), the effect of strategic planning can be positive or negative, which depends on three variables, those being stakeholder behavior, participatory nature, and the planning of group psychological characteristics.

In the literature, crucial strategic orientations are highlighted, and these are successful in government planning (Mcmahon \& Phillimore, 2013), and more recently, when seen in public-sector characteristics (Favoreu, Carassus \& Maurel, 2016). This multiplicity approach aligns with Johnsen (2015), which indicates that strategic management in the public sector draws heavily on strategic planning associated with several other approaches.

The literature shows a lack of leadership and fluidity in strategic planning hindering an effective contribution to government reforms (Kayuni, 2017), also that there are inadequacies between strategic plans and the approach concerning emergency situations (Oloruntoba, 2013). However, strategic planning is significant for development 
transformation (Mawela, Twinomurinzi \& Ochara, 2017), for the process of strategic changes in the face of turbulent environments (Pasha \& Poister, 2017) and in environments of complex policy (Rinaldi, 2016). The recent literature on strategic planning and the public sector also includes the evaluation of integration between hiring processes and strategic planning (Staples \& Dalrymple, 2016).

BSC axis are commonly addressed by strategic planning studies in public administration, these usually include strengths, weaknesses, opportunities, and threats (Bryson, Edwards \& Van Slyke, 2018). Moreover, the editorial article by Bryson, Edwards and Van Slyke (2018) presents a special edition article and suggests as research agenda studies on operationalization and the effects of strategy dimensions.

\subsection{BALANCED SCORECARD}

As addressed previously, strategic management in the public sector has a wider focus on the planning phase. Execution and evaluation need to be included in this cycle, in order that strategic objectives are achieved and no problems occur, as well as a diagnosis of the actions taken as a means to deepen changes in the public sector (Bryson, 1988; Moore, 2002).

Therefore, the concept of strategic management should be broad, with the inclusion not only of the strategy, but also the implementation and evaluation of the strategy (Mintzberg, Lampel \& Ahlstrand, 1999). The BSC strategy tool is an alternative to this problem, which allows for a better understanding of strategic objectives linked to organizational perspectives, as well as inserting greater strategic control by measuring through use of indicators, along with establishing cause and effect relationships (Kaplan \& Norton, 1992, 2000).

Another advantage of the BSC is the inclusion of other perspectives that do not focus on financial aspects. This aids in producing the holistic view of organizations and in understanding other non-financial factors that may influence organizational performance (Kaplan \& Norton, 1992, 2000). A tool previously used for BSC was the Tableau de Bord, which divided financial and non-financial data for information management and control in industries. However, the BSC addresses new perceptions for the strategic management of organizations (Epstein \& Manzoni, 1997; Quesado, Rodrigues \& Guzmán, 2012).

In general, the BSC is an organizational strategy management control system that allows the manager to approach businesses in four essential perspectives (Kaplan \& Norton, 1992) - customer, internal processes, learning and financial. Moreover, BSC processes help to improve strategic control, facilitating communication and provide a more integrated perspective (Norreklit, 2000, Queiroz \& Lobosco, 2015).

In the Brazilian context, the Fundação Getúlio Vargas (FGV, 2016) and the National School of Public Administration (ENAP, 2014) highlight the potential contribution for BSC by translating the strategy into operational objectives, structuring the measurement 
system of the organization, recognizing the indicators, communicating the strategy, aligning the strategy with business and strategic learning.

The strategic map as cited by Kaplan and Norton (2000) is a BSC support tool and provides a visual framework for the organizational objectives regarding the four BSC strategic perspectives (financial, customer, internal processes, learning and growth).

The adoption of the strategic map helps to illustrate how the organization transforms initiatives and resources (including intangible assets such as corporate culture and employee knowledge) into tangible results (Maar, Schiuma \& Neely, 2004). Another contribution includes the representation of the cause and effect relationship of the strategic objectives (Quezada, Cordova, Palominos, Godoy \& Ross, 2009).

Grouping information is one of the advantages of using the BSC, as it limits the number of prospects to four, such information can be based on customer orientation, reduced response time, increased quality, use of teamwork and focus on change with identification (Kaplan \& Norton, 1992, 1996).

\subsection{BSC IN THE PUBLIC SECTOR}

Some authors suggest that the adoption of BSC by public organizations is part of a broad wave of ideological policy-driven reforms (Bobe, Mihret \& Obo, 2017), which establish the adoption of accountability and accountability tools in the private sector. However, the literature also shows the BSC potential to address the multi-stakeholder approach issue in the public sector (Mcadam, Hazlett \& Casey, 2005).

BSC changes have been developed to suit public sector issues, such as the public sector scorecard (PPS), which is an integrated performance management framework that incorporates strategic mapping, service improvement, measurement and evaluation (Dimitropoulos, Kosmas \& Douvis, 2017).

The study by Bracci, Maran and Inglis (2017) focuses on performance, system design and BSC implementation in two Italian public service organizations. The authors Plaček, Půček and Šilhánková (2017) carry out the strategic management study of museums in the Czech Republic, identifying weaknesses and best practices, as well as presenting optimal performance indicators for the segment. Some studies focus on national level organizations, such as in the case of the analysis of a large Ethiopian public health organization (Bobe, Mihret \& Obo, 2017). Only a few studies focus on robust quantitative research techniques. In Grigoroudis, Orfanoudaki and Zopounidis (2012), for example, the authors conducted a multicriteria decision-making (MCDM) study, using the BSC framework to evaluate the strategic performance of health organizations.

Other studies investigate performance management in the public sector, while approaching the integration of BSC in performance management (Mcadam, Hazlett \& Casey, 2005). In this sense, when looking at organizations of higher education, the literature shows that organizations whose financial strategies are better related to 
educational returns are more likely to succeed, even with changes in their funding model (Schobel \& Scholey, 2012).

Different governments have used the BSC to develop performance models for more transparent, efficient and effective management (Sutheewasinnon, Hoque \& Nyamori, 2016). Apart from the perspective of the BSC as a performance tool, other BSC approaches focus on improvement of the strategic alignment through integrated planning (Bobe, Mihret \& Obo, 2017). In this way, part of the literature sees BSC as a performance measurement tool (Northcott \& Taulapapa, 2012).

Although literature concerning BSC in the public sector proposes a framework, Yuen and $\mathrm{Ng}$ (2012), for example, focuses on the development of a theoretical framework for the application of BSC in a Chinese hospital organization. Few studies have been found that focus on public educational organizations. In this sense, some authors have evaluated the application of BSC to evaluate higher education schools (Schobel \& Scholey, 2012).

In Brazil, there are few studies that focus on the application of BSC in the public sector. Existing studies are aimed at federal public agencies (Felix, Felix \& Timóteo, 2011). The number of studies pertinent to the application of the BSC in Brazilian public schools are even lower, with these being focused on the efficiency of the educational system as a whole and not on the specific reality of school strategic management (Mizrahi \& Canen, 2012). However, no article proposes a theoretical framework for understanding their applicability nor develop a model for public educational organizations.

Finally, we positioned the theoretical framework in order to synthesize the background of the bibliographic review. It should be noted here that this framework was used as a support for the data discussion on the theoretical view (Frame 1):

\begin{tabular}{|l|l|l|}
\hline \multicolumn{1}{|c|}{ Topic } & \multicolumn{1}{|c|}{ Definition } & \multicolumn{1}{c|}{ Authors } \\
\hline $\begin{array}{l}\text { Strategic planning in } \\
\text { the public sector }\end{array}$ & $\begin{array}{l}\text { Strategic planning in the public } \\
\text { sector helps with implementation, } \\
\text { but it should include the stages of } \\
\text { implementation and the strategic } \\
\text { control }\end{array}$ & $\begin{array}{l}\text { Mintzberg, Lampel \& } \\
\text { Ahlstrand, 1999; Staples \& } \\
\text { Dalrymple, 2016 }\end{array}$ \\
\hline $\begin{array}{l}\text { The Balanced } \\
\text { Scorecard }\end{array}$ & $\begin{array}{l}\text { The Balanced Scorecard tool helps } \\
\text { with integration of the strategic } \\
\text { cycle, adding new perspectives for } \\
\text { understanding organizational reality }\end{array}$ & $\begin{array}{l}\text { Kaplan \& Norton, 1992; 2000, } \\
\text { Norreklit, 2000 }\end{array}$ \\
\hline $\begin{array}{l}\text { BSC in the public } \\
\text { sector }\end{array}$ & $\begin{array}{l}\text { Internationally. There are more } \\
\text { studies on the application of BSC in } \\
\text { the public sector. In the Brazilian } \\
\text { scenario, there are few studies and } \\
\text { in the scenario of public-school } \\
\text { lesser still. }\end{array}$ & $\begin{array}{l}\text { Northcott \& Taulapapa, 2012; } \\
\text { Felix, Felix \& Timóteo, 2011; } \\
\text { Mizrahi \& Canen, 2012 }\end{array}$ \\
\hline
\end{tabular}

Frame 1 - Schematic framework of the background theory

Source: Prepared by the authors. 


\section{RESEARCH METHODS}

This research study was developed within a qualitative exploratory framework, from an applied perspective, that generates knowledge for the practical application, addressing the solution of specific problems (Silva \& Menezes, 2005). The analysis has a descriptive perspective, which directs the presentation of characteristics from a given population or phenomenon (Cooper \& Schindler, 2013). The technique used for data collection was the case study, allowing the knowledge and information and analysis to be performed in a broader and more detailed fashion (Silva \& Menezes, 2005, Cooper \& Schindler, 2013).

For an improved understanding of the steps in this research study, a visual schedule was created, as seen in Figure 1:

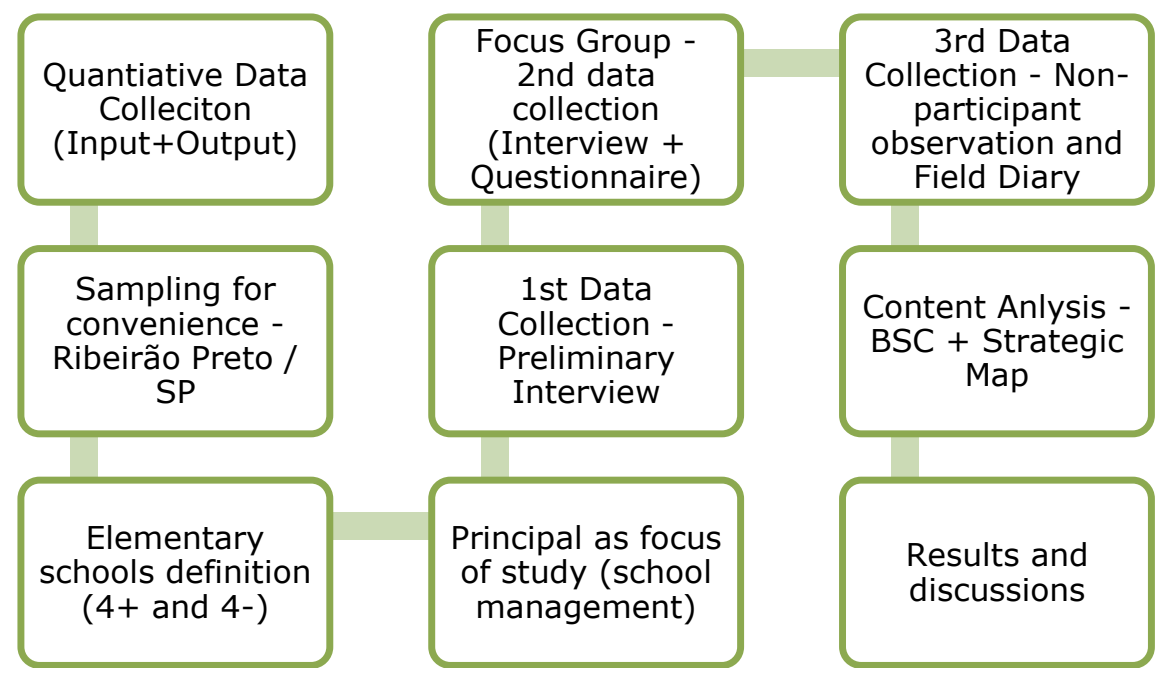

Figure 1 - Schematic framework of the method

Source: Prepared by the authors.

\subsection{PRELIMINAR ASSESSMENT}

The first step of the study involved the collection of quantitative data on school performance with the annual municipal investment per student, the socioeconomic level (NSE), with the infrastructure as input and the performance in the IDEB as output. Municipalities and schools were divided according to socioeconomic level 2 and $3 ; 4 ; 5$ and 6 , with 2 and 3 representing the worst and 5 and six the best. Of these, the only municipality that presents more than 20 schools, in the state of São Paulo (placed as a necessity of the study in question, i.e., for a more extensive sample of schools), was track 5 and 6. 


\subsection{SAMPLE}

From the preliminary survey, the city of Ribeirão Preto, located in São Paulo state, was chosen, through its size, as a municipality for the investigation of public schools. Through its possessing 600.000 habitants, the city does not suffer from small town financing issues, neither does it have the benefits of the state capital, which can represent two major research bias. Consequently, contact was made with the Education Department of the city to use some basic level public schools as an object of the research conducted herein. Four schools with the best performance (School A, School B, School C and School D) and four worst-performing schools (School E, School F, School G and School H) were chosen from within the same socioeconomic range, as previously explained.

In terms of school administration, the school principal is primarily responsible, as this individual is in charge of creating a team for assisting in administrative and pedagogical functions. The principal provides attributions to school management, coordinating human effort and is responsible for the proper functioning of the school (Paro, 2010). In this way, the principal determines a significant part of the school management, being responsible for the integration coordination and results achieved by the school (Neto \& Castro, 2011). It is the principal who composes teams, coordinates human effort and assumes a high responsibility for school management (Paro, 2010). Thus, data collection is focused on the perspective of school principals.

\subsection{DATA COLLECTION}

In this research study, the technique of data collection was performed through use of the field diary, observation, questionnaire, focus group and interview. The semistructured interview (Silva \& Menezes, 2005) was developed from two scripts, one during the interviews and the other after the focal group. The scripts had opened, closed, and multiple-choice questions to gather the information needed to conduct the study. A questionnaire was also used to evaluate the perceptions of respondents after termination of the focus group and training. Noteworthy here is that all interview scripts underwent a pre-test before being applied. Eight semi-structured interviews were conducted with each school principal.

The focus group was used to obtain information on four subsequent encounters (Berg, 1998). Initially, all 08 principals were invited to perform this stage, but only three (School B, School C, and School G) attended the meetings.

The objectives of the interview scripts are to transform the desired information into questions, to motivate the interviewee toward providing answers and complete the script (Malhotra, 2012). The questionnaire was used in the focus group stage to identify the perception and reaction of the school principals for the applied stage. 
The non-participant observation that was used in the study consists of the effective interaction of knowledge in the current situation of society, the group or a specific situation (Cooper \& Schindler, 2013). It can be understood as a peculiarity of observation. From the two previous steps, interviews and focus group, two schools (one high school and one lower school level) were identified in both stages for non-participant observation, and the researcher spent two days in each school (School B and School G) to understand why there existed a performance difference between them.

The field diary, which works as the investigation of affective, cognitive and social processes in greater detail, was used in the three stages of the research study, those being interviews, focus group and non-participant observation, where notes were taken by the researcher (Zaccarelli \& Godoy, 2005).

\subsection{CLASSES AND DATA ANALYSIS}

The categories used in this article were BSC and strategic map: a management control system of organizational strategy in four perspectives (client, internal processes, innovation \& learning and financial) and the strategic map is a visual framework for the organizational objectives of the four perspectives cited; and the specificities of public management, understood by the particular characteristics of management, so that the organization achieves its objectives, such as following laws, political environment and not seeking profit, but rather the quality of services for society. The research questions used in this study were the following: What is the adequacy of the possible use of the BSC and strategic map? What are the characteristics of the BSC and strategic map in the strategic management of public schools?

The data analysis technique used was content analysis, which is organized into the following steps of pre-analysis, material exploration and treatment of results obtained and interpretation (Neuendorf, 2002).

\section{DISCUSSION RESULTS AND RESULT ANALYSIS}

The interview phase described the schools and the school principals of the research study, and also pointed out concepts about the public administration practiced, along with the importance of the school plans, as for example, the Political Educational Project (PPP), Teaching Plan and Classroom Plan. This phase highlighted that schools did not use the School Development Plan (PDE) (Brazil, 2016). Some of the institutions included in the study had already used an interview phase, when they were defined as priority schools (schools with poor performance), as a project to improve educational levels and linked to the transfer of financial resources from the federal government to carry out programme activities. 
Schools received funding from the federal government through the Direct Money in Schools Program (PDDE). The PDE was updated to Interactive PDDE, which is a management tool for and of the public school. The schools from which principals were interviewed received the PDDE from the federal government, the Interactive PDDE acted much more as a criterion for receiving the resource than efficiently as strategic management of the schools.

For strategic management, the principals that participated in the interviews pointed out that the schools had strategic planning, mainly linked to their Political Pedagogical Project (PPP). Most schools had only the values formalized in their PPP. Another observation made is based on the realization of the Pedagogical Political Project as a pedagogical tool and not as an administrative tool. Thus, when used as a tool of strategic planning, it becomes a failure. The establishment of a specific strategic management plan would be a breakthrough in terms of the future performance of schools.

All the principals interviewed stated that they did not know of the BSC tool and strategic map for strategic management. Likewise, these also had never been trained in strategic management. The conceptions of strategic management based on the viewpoint of the principals were of the most diverse (Queiroz \& Lobosco, 2015), with the following being mentioned:

- The manager must always be ready to analyze the strategy applied and together with the school staff and parents adapt it and improve it when necessary;

- The way that it is administered and is applied to the school needs to reach the desired goal (good education provided for the students);

- Take care of everything, always using the strategy to improve the educational and administrative plan over the long term;

- Flexibility to deal with diversities in every way;

- Use different paths to achieve one main goal, understanding the school as a whole;

- Set goals and prepare strategies, so that goals are achieved on a daily basis;

- The need to draw up various plans, where it is essential these do not lead to conflict situations;

- Everything that should be done to make good progress within the school and provide a better performance to the student;

- One applies the understanding of how to think of goals and objectives in terms of improvement in the life of the student while at school.

The focus group presented the emergence of the BSC, its use, the theoretical content of the BSC perspectives and their practical applications, an adaptation of perspectives and as a tool for the public sector. Subsequently, authorization was questioned, as to how it was granted and applied in research with the municipal schools of Ribeirão Preto/SP, while explaining that the initial contact was through the Municipal Secretary of Education of 
Ribeirão Preto and after reading the qualification, authorization was granted through an office for conducting the research study.

The focus group explored the application of the BSC to specific sectors and discussed two articles that deal with the application of BSC in public schools (Canan, 2005). The principals have raised the possibility of the management team being composed of a general principal, an administrative coordinator and a pedagogical coordinator. They also pointed out that, in schools, the management team learns through practice, since the Pedagogy course does not offer subsidies for school management. The discussion of the plans was resumed, with the proposition of the BSC as the private administrative plan enacted in the administrative part, which includes strategic management.

The proposal of the application of the BSC to the reality of the school was presented, respecting the particularities of each school unit. The principals pointed out that the schools need mechanisms to strengthen the learning of the student body. Thus, the BSC would be used as an evaluation of the organization as a whole, both in pedagogical and administrative aspects.

The evolution of the concept of the BSC was presented with the emergence of the strategic map, its concept, elaboration, characteristics, exemplification of the map for a fuel distributor and its advantages. Then, the use of the strategic map in the public sector was shown, for such, change of the perspectives concerning the name and function is necessary, besides the alteration of the order of presentation. The authors herein have presented cases for the use of the strategic map in the public sector and the discussion of the strategic map of the Federal Public Ministry. Discussed also were some of the phases of the Brazilian public administration, Pluriannual Planning (PPA), Annual Budgetary Law (LOA) and Budgetary Guidelines Law (LDO).

A strategic map implementation case was presented in the Fulton County School System (United States). Next, we discussed each of the strategic objectives of the perspectives worked out for the case.

Finally, the results of the case for the application of the strategic map in the educational system of Fulton, in the United States, were presented. Next, a case was worked out for the public sector of the UK Ministry of Defense and the results of this application in terms of the case cited. Following this, the outline of the BSC was made for a public school with the following perspectives and questions:

- School community perspective (How does the school community see the school?) (Customer perspective);

- Innovation and learning perspective (Can the school improve and generate value for its employees, infrastructure, and technology?) (Innovation and learning perspective);

- Resource perspective (How does the school use its resources (staff, infrastructure, and budget)? (Financial perspective); 
- Pedagogical and administrative processes perspective (What should the school do to improve pedagogical and administrative aspects?) (Perspective of internal processes).

With this general reference, the outline of a strategic map for public schools was presented (Figure 2). Noteworthy here is that the strategic objectives were based on Canan (2005) and Kaplan and Norton (2004). The perspectives were as follows school community at the top (old customer perspective), followed by the perspective of pedagogical and administrative processes (the old perspective of innovation processes), the perspective of learning innovation (original name was maintained) and perspective of resources (the old financial perspective). This was divided into the political dimension and instrumental dimension, with the more significant objective being defined by improving the quality and efficiency of public education. Also represented was the traditional strategic map, with an alert concerning the order of traditional presentation for the perspectives.

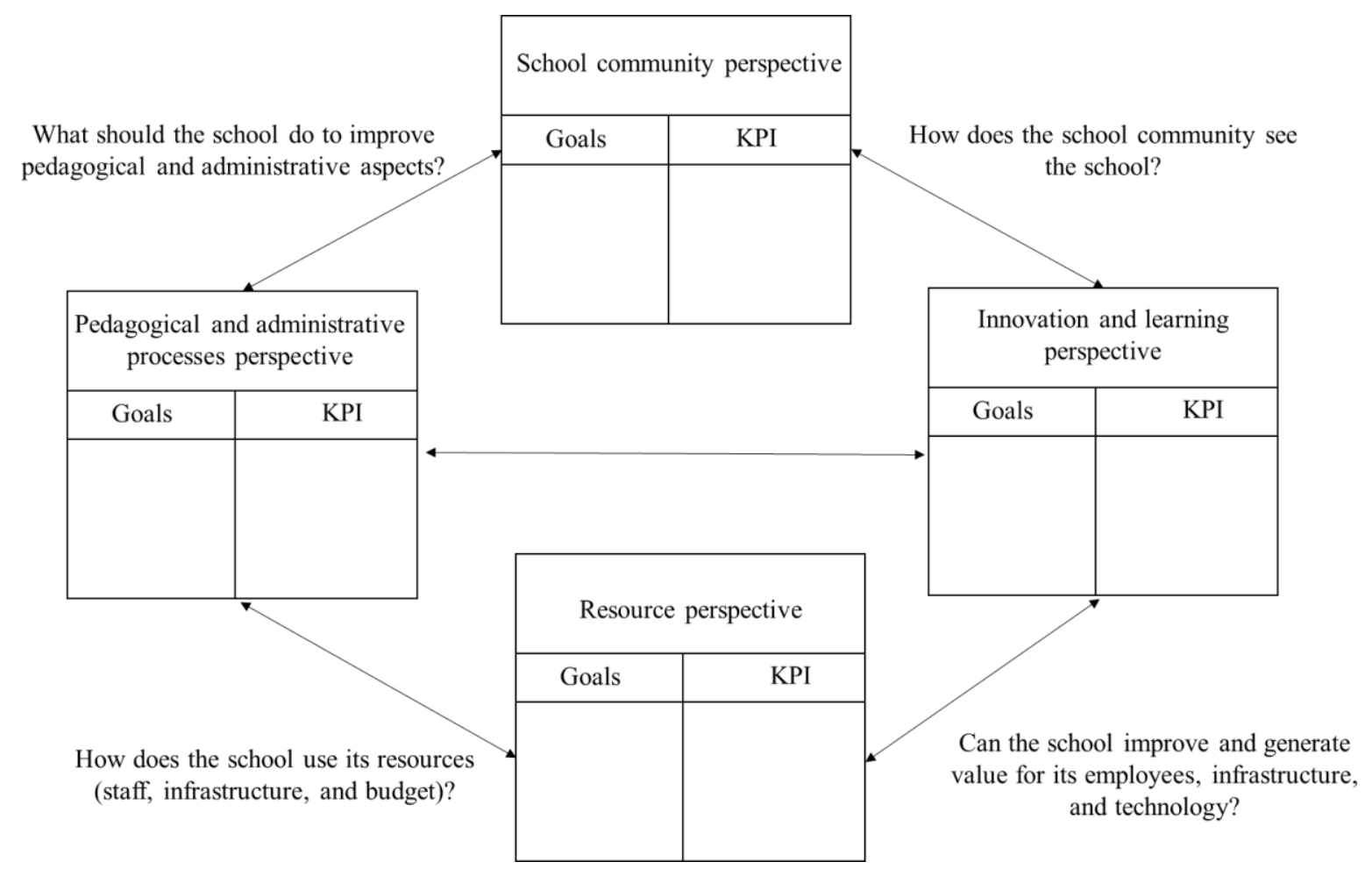

Figure 2 - Balanced Scorecard Framework in School Management

Source: Prepared by the authors.

Each perspective and strategic objective was discussed, Figure 3 shows the latter draft model discussed. Each perspective is composed to the following strategic objectives:

- School community perspective: improvement of learning and mastery of the curriculum; active parental involvement in the school board and APM; safe and enriching climate in school; attendance of the local community with vacancies in the school; improvement in IDEB. 
- Pedagogical and administrative processes perspective: attends to pedagogical and political plan, attendance of the school plan and lesson plan, new didactic resources, and library operation, quality school meals; action plan (administrative).

- Innovation and learning perspective: trained and motivated teachers and staff; information systems; knowledge management.

- Resource perspective: availability of material resources, maintenance of infrastructure; retention of teachers and staff; compliance with the budget.

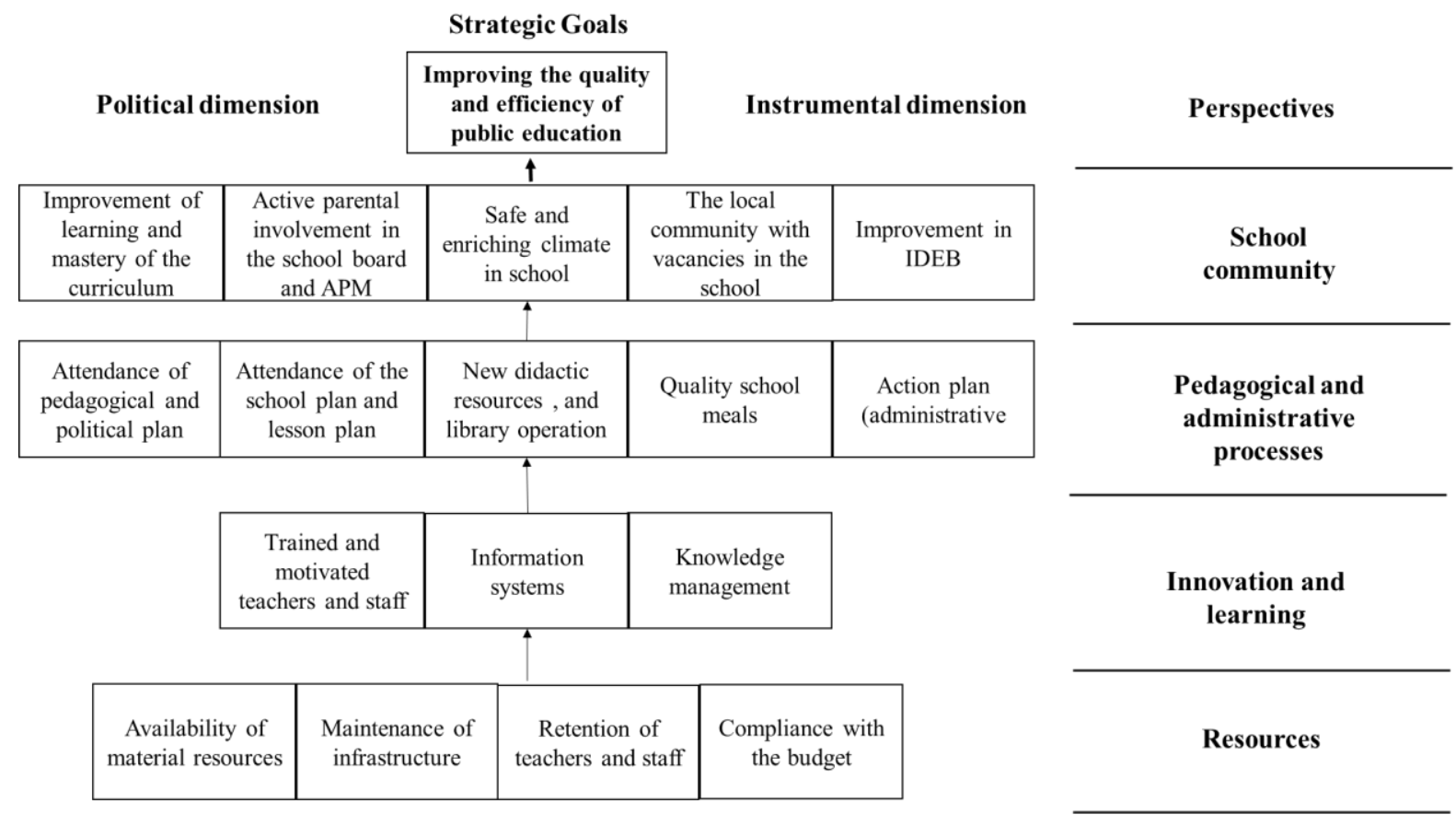

Figure 3 - Strategic Map Framework in School Management

Source: Prepared by the author.

The BSC was drafted along with a strategic map for public schools. There exists a need for the establishment of clear goals by the school. The necessary adaptation of each tool was made with the adaptation of the perspectives and function of the BSC and rearrangement of the layout of the perspectives concerning the strategic map (Kaplan \& Norton, 2000). All principals agreed on the BSC's presenting models and a strategic map. They agreed on the grouping of the "community" perspective containing parents and students. Principals cited some school cases where it is necessary to call the student's parent to the school to discuss issues of student indiscipline, and that often parents do not take responsibility for misbehavior and blame the school.

In regards to the application of the BSC in the public sector, mention was given to it as a possible means of producing more explicit ideas concerning the administrative part, thus allowing the manager to take a general look at the organization in order to accomplish 
the strategy (Maccarone et al., 2014; Rahiminia \& Karzogar, 2016; Souza \& Cordeiro, 2010, Younis \& Knight, 2014). The principle also justified the search for the proposed objectives and that, with the BSC, the official plan will not be left "in the drawer." On the understanding of the application of the strategic map in the public sector, the principles stated that the strategy is more transparent with the use of the strategic map because it shows the cause and effect relationship of the objectives and draws the actions that will be sought. They pointed out the importance of the strategic map in the implementation.

In terms of the possible use of the BSC and strategic map in the school setting, management stated that through the BSC, it will be possible to follow a long-term goal planning, and not having to deal with every problem as an emergency issue Northcott and Taulapapa (2012). The principles also cited the adequacy of the names and functions of the BSC perspectives and the reordering of the presentation of the perspectives of the strategic map. The constraints on the use of strategic management in the public sector were lack of financial resources, political factors, wrong people in wrong positions, legislation (old laws), lack of technical personnel, lack of professionalism and the issue of indication through a political factor, without considering technical factors of knowledge (Mcadam, Hazlett \& Casey, 2005). The benefits of using strategic management in the public sector have been the alignment in management, long-term look, which brings improvements to strategic management (Kaplan \& Bower, 1999). The benefit of the holistic view of the school was also highlighted.

The specificities of school management for the use of strategic management were the focus on student satisfaction and learning, goals more oriented to the pedagogic, while they should include both administrative and pedagogical aspects in strategic management (Schobel \& Scholey, 2012). A questionnaire was used to evaluate the reaction of the principals in the focus group. Overall, the focus group was evaluated highly by the participating school principals.

During the non-participant observation phase, identification was made of the main activities performed by the principal in their daily routine. The previous phase of the focus group study was discussed. The principal said that this phase was positive. After applying the phase, the focus group thought about how it could apply the strategic management in the school. The two principals pointed out that they need strategic management to think long-term and stop the "put out the fire" situation in which the school currently functioned, with the proposal of more considerable planning, organization and laying out of organizational routines and objectives.

The principal of School B stated that he had not yet had time to study and reflect on the focus group. He said he wanted to print all the material to ponder on it. He spoke about the current situation of problem-solving (fire extinguisher) and also stated that it was a tool that he did not know and that, if implemented, could bring improvements. The principal 
of School G pointed out that the training helped her to think of the school as a whole, as well as produce more appropriate planning with the teachers and students and in fact bring an end to the so-called "putting out fires" situation. She also mentioned the moment of conversation with the other principal, in the sense of building collective knowledge and learning new concepts, such as the strategic map, addressing both the administrative and the pedagogical aspects, with a long-term vision.

In general, the principals interviewed had little knowledge about strategic management, although they did formulate some strategic actions intuitively or that were contained within the political-pedagogical projects. Through the training and focus group, the principals began to gain more significant knowledge on some topics within the strategic literature. The restrictive factors of the use of strategic management in the public sector and public school circulate around political factors. The potential factors are communication and participation. The BSC and the strategic map appear as viable within the public sector and public schools. However, both need to be adapted for the best use possible. These adaptations would be changing the name of the perspectives, changing the function of the perspective, rearranging the order of presentation of the strategic map perspectives. The evidence found for the specificities were the goals principally directed toward the pedagogical, lack of personnel, public school that aims at the satisfaction of society, restriction of resources, participation of the school community in the decisions, influence of the environment in which the school is inserted and influence of political factors, mainly of the municipality.

The interview step contributed to greater knowledge of the routines and peculiarities of the schools and their respective principals. The focus group phase served to obtain the data for the general outline of the BSC and strategic map. The non-participant observation phase contributed to ascertain the way in which each principal deals, potentially and in practice, with the management of the municipal public school. In this way, it was possible through using due adaptations, to present the BSC and consequently, the strategic map as tools that could be used to confront and plan the contingent environment in which the schools are inserted.

\subsection{REVIEWING THE BACKGROUND THEORY AND SINTHETYZING THE FINDINGS}

This study helps to connect the strategic cycle, understanding the relationship of planning steps, along with implementation and evaluation (Mintzberg, Lampel \& Ahlstrand, 1999; Staples \& Dalrymple, 2016). It is understood that strategic management is of real assistance to the present and the future of public organizations, as well as having a positive effect on the participation of educational players and the school community, as it increases within the investigated scenario (George, 2017; Poister, 2010).

The strategy may have a positive role in the plans of public schools, often marked by the absence of developed administrative programs (Favoreu, Carassus \& Maurel, 2016; 
Johnsen, 2015; Mcmahon \& Phillimore, 2013). The leadership role for the development of strategic management in schools is a crucial point, marked by the predominant role of school management decisions (Kayuni, 2017). Emerging strategies are also a difficulty in public schools, which makes it harder to implement certain actions (Oloruntoba, 2013).

As shown in the literature, the adoption of strategic planning can really improve the relationship of the public school with its environment, understanding new situations that can change the established course of action. Furthermore, the setting of participatory strategic plans can alter the development of changes in the school scenario and in the improvement of administrative and pedagogical performance (Mawela, Twinomurinzi \& Ochara, 2017; Pasha \& Poister, 2017; Rinaldi, 2016).

The operationalization of the BSC in the school reality, through the understanding of new dimensions and perspectives, is another topic for study in the research agenda of the strategy (Bryson, Edwards \& Van Slyke, 2018). The BSC also helps to layout the strategic objectives and evaluate the results achieved, thus constituting the tool that is able to incorporate the relationship between areas and in the holistic view of the organization (Mintzberg, Lampel \& Ahlstrand, 1999; Staples \& Dalrymple, 2016).

The financial part of public schools is still heavily tied up, depending on the guidance of the municipal secretaries of education. So, the inclusion of new perspectives for strategic management are particularly important, since it can be a tool that suits the reality of the school. Another point is that the tool attests to the flexibility in model adaptations, which is in line with literature and established by Kaplan and Norton, 1992, 2000, Maccarone et al., 2014, Rahiminia and Karzogar, 2016, Souza and Cordeiro, 2010 and Younis and Knight, 2014.

Another consistent point in line with the literature was the importance of BSC in the management of the organization itself (ENAP, 2014; FGV, 2016), understanding the development of new organizational routines, new communication channels, relationship of the cause and effect concerning strategic objectives and the importance of participatory strategic processes (Kaplan \& Norton, 2000; Maar, Schiuma \& Neely, 2004; Norreklit, 2000; Queiroz \& Lobosco, 2015; Quezada et al., 2009). At this point, it was important to elaborate not only the BSC, but also the strategic map together with the school principals.

Once again, the research carried out brings a new topic to the discussion (Bryson, Edwards \& Van Slyke, 2018), this is noted through the reality of the Brazilian public sector and Brazilian public schools, which is a differential to be analyses. Most studies are international, for this reason the importance of studies addressing the reality of Brazil exist.

For example, there are different approaches to the use of BSC in the international public sector, such as accountability system (Bobe, Mihret \& Obo, 2017), stakeholder management (Mcadam, Hazlett \& Casey, 2005), strategic management system 
(Dimitropoulos, Kosmas \& Douvis, 2017), performance management (Grigoroudis, Orfanoudaki \& Zopounidis, 2012), evaluation of indicators (Bracci, Maran \& Inglis, 2017) and financial management of educational organizations (Schobel \& Scholey, 2012).

In Brazil, studies are aimed at federal public agencies (Felix, Felix \& Timothy, 2011) or with more general approaches to strategy and BSC (Mizrahi \& Canen, 2012). This study has the importance of focusing on the specific reality of public school, developing of the $\mathrm{BSC}$ and the strategic map from the reading of the directors that are participating in the research.

In addition, the advantages brought forth in the literature on BSC and the strategic map were identified from the design of the frameworks (Bobe, Mihret \& Obo, 2017, Northcott \& Taulapapa, 2012, Sutheewasinnon, Hoque \& Nyamori, 2016) as a tool for participatory management, strategic alignment and performance management.

Finally, some of the main findings of the study are summarized, relating to the theoretical background performed (Frame 2).

\begin{tabular}{|l|l|}
\hline Topic & Findings \\
\hline Strategic planning in public sector & $\begin{array}{l}\text { There is plenty of room for the development } \\
\text { of strategic management in the public } \\
\text { sector. Implementation and evaluation } \\
\text { remain challenges in the area. }\end{array}$ \\
\hline The Balanced Scorecard & $\begin{array}{l}\text { The Balanced Scorecard and the strategic } \\
\text { map are useful, flexible and integrative } \\
\text { tools for the management of organizations }\end{array}$ \\
\hline BSC in public sector & $\begin{array}{l}\text { There is a great space for the application of } \\
\text { the BSC and the strategic map in the } \\
\text { Brazilian public sector. The tools need to be } \\
\text { aligned with the reality of each object, as in } \\
\text { the case of the elaboration of the } \\
\text { instruments by the school directors }\end{array}$ \\
\hline
\end{tabular}

Frame 2 - Schematic framework of the findings

Source: Prepared by the authors.

\section{FINAL CONSIDERATIONS}

The paper developed herein may generate several views and new ideas for the use of strategic planning in school management, i.e., it will provide new tools for public managers for development in their work, especially in the management of public schools.

The first lesson learned, in this case, is that all public-school managers were not aware of the strategic planning tools, while using PPDE intuitively and without prior 
knowledge of the tool, including the BSC which was later presented and developed through their participation.

Subsequently, using interviews, focus groups and other methods, it was noted that the BSC is a fundamental and extremely important tool for school management, while creating a model adapted for its use in 4 adapted perspectives of its reality: School community perspective - How does the school community see the school? - (Customer perspective); Innovation and learning perspective - Can the school improve and generate value for its employees, infrastructure, and technology? - (Innovation and learning perspective); Resource perspective How does the school use its resources with staff, infrastructure, and budget? - (Financial perspective); Pedagogical and administrative processes perspective - What should the school do to improve pedagogical and administrative aspects? - (Perspective of internal processes). In this way, a strategic map can be created for the management of public schools, a fundamental tool for the good management of any organization (Figure 3).

Finally, after the implementation of the research project, there was an observed need for school managers to acquire more knowledge about strategic planning in school management, to develop and adapt the more general strategic planning for their school. In addition, one of the limiting factors pointed out for the use of the BSC as a tool of strategic planning is the political factor, with its suffering of constant changes all the BSC created can undergo drastic changes.

Therefore, we have achieved our goal by developing a framework and identifying the vision of the principal in strategic management with BSC and strategic mapping in the public sector. The perspective of the strategic management for the principal was seen as involving the definition of goals and objectives, predominantly to improve the life quality of the student.

The vision of the principal on the application of strategic management with BSC and the strategic map in the public sector indicates the possibility of its application, provided that the model is adapted to the reality of the public school. The framework involved the idea of long-term planning using goals, from the elaboration of a tool for the administrative part that seeks long-term goals, with structured planning by the BSC and a comprehensive view of the school. Furthermore, this tool would complement the pedagogical part and from the strategic map, a visual picture of the cause and effect relationship between the proposed objectives would be indicated.

From among the results, the authors highlight the appropriateness of the model for the use of BSC and the strategic map for the specific approach of school organizations. Among the necessary adaptations changes are made to the name of the perspectives; the perspective of the strategic map, with the following proposal: school community at the top, followed by the perspective of pedagogical and administrative processes, the perspective 
of innovation and learning and the perspective of resources at the bottom. Noteworthy here is that the characteristics of the BSC and the strategic map in the strategic management of public schools, before the research study, were unknown by the participating school principals.

The Principals understood the importance of strategic management and the use of a tool such as the BSC and strategic map to improve school management activities, and the move away from the current situations of only solving problems. Through the instituted fieldwork, the characteristics of the BSC and the strategic map were understood as being tools for the elaboration and implementation of the long-term strategy. Similarly, the principals elaborated a visual framework that points out the relationship between the strategic objectives

This article is useful for the academic community, public managers, and public-school principals by providing the design of BSC frameworks and the strategic map that can be adapted to other public organizations and public schools. Thus, new instruments are available for strategy designs, which can help improve the performance of school units, both in pedagogical and administrative aspects.

It is not yet understood how the adoption of the BSC and the strategic map would happen in practice in terms of school organizations, as there are no studies in this sense. From scientific studies, it is known that both tools have several benefits when used in the public sector. Therefore, advantages in the application of BSC and the strategic map in these organizations have been noted. This research study fits into this context, as it is the first initiative of its kind provided for municipal public schools in using strategies that improve participation and performance.

One aspect that can be taken from this study is that there is a lot of room for the development of strategic management in the public sector, especially in public schools. In addition, the importance of knowing the reality of the object of study for the development of valid options for organizational innovation is of the upmost importance. Consequently, the frameworks developed are valid in the way they were developed. This research study brought detailed exposure of BSC development and strategic map, as well as the relationship with the relevant literature. Therefore, this advances knowledge of the area by indicating how school organizations can improve their performance.

The limitation of the study is found in the low participation of school principals in the focus group phase, sampling was small for a broad perspective of the model, but it does, however, provide a basis for understanding the variables involved in the strategic planning process using BSC in educational public sector organizations, and the lack of quantitative approach, when laying out the models proposed. Furthermore, we revealed two situations that are still under explored by academics: the strategic planning approach in educational organizations and the BSC approach in Brazilian organizations (theoretical). 
The propositions for future studies, including these contributions: development of a specific BSC practical model for educational organizations, quantitative approach for improvement of frameworks, new research studies applying the theme in other regions in Brazil and in the other countries, application of an adaptive BSC model in other areas of public administration, such as public health, city development and public security.

\section{REFERENCES}

Berg, B. L. (1998). Qualitative research methods for the social sciences. Boston: Pearson.

Bobe, B. J., Mihret, D. G. \& Obo, D. D. (2017). Public-sector reforms and balanced scorecard adoption: an Ethiopian case study. Accounting, Auditing \& Accountability Journal, 30(6), 1230-1256.

Bracci, E., Maran, L. \& Inglis, R. (2017). Examining the process of performance measurement system design and implementation in two Italian public service organizations. Financial Accountability \& Management, 33(4), 1-16.

Brazil. (2016). Ministério da Educação. Apresentação do programa dinheiro direto na escola. Brasília: FUNDESCOLA.

Bryson, J. M. (1988). Strategic Planning for Public and Nonprofit Organizations: A Guide to Strenghering and Sustaining Organizational Achievement. San Francisco: Jossey-Bass Inc.

Bryson, J. M., Edwards, L. H. \& Van Slyke, D. M. (2018). Getting strategic about strategic planning research. Public Management Review, 20(3), 317-339.

Canan, I. (2005). Subsídios para o uso do balanced scorecard nas instituições públicas de educação básica. Anais Congresso Internacional de Custos, 9, Florianópolis, SC, Brasil.

Cooper, D. \& Schindler, P. (2013). Business Research Methods. New York: McGraw-Hill Education.

Dimitropoulos, P., Kosmas, I. \& Douvis, I. (2017). Implementing the balanced scorecard in a local government sport organization Evidence from Greece. International Journal of Productivity and Performance Management, 66(3), 362-379.

ENAP. Escola Nacional de Administração Pública. (2014). Gestão da estratégia com uso do BSC. Brasília: ENAP.

Epstein, M. J. \& Manzoni, J. F. (1997). The balanced scorecard and tableau de bord: translating strategy into action. Strategic Finance, 79(2), 28-36.

Favoreu, C., Carassus, D. \& Maurel, C. (2016). Strategic management in the public sector: a rational, political or collaborative approach? International Review of Administrative Sciences, 82(3), 435-453.

Felix, R., Prado Felix, P. \& Timóteo, R. (2011). Balanced Scorecard: adequação para a gestão estratégica nas organizações públicas. Revista do Serviço Público, 62(1), 51-74. 
FGV. Fundação Getúlio Vargas. (2016). Curso auto instrucional Balanced Scorecard. São Paulo: FGV.

George, B. (2017). Does strategic planning 'work' in public organizations? Insights from Flemish municipalities. Public Money \& Management, 37(7), 527-530.

Greatbanks, R. \& Tapp, D. (2007). The impact of balanced scorecards in a public sector environment. International Journal of Operations \& Production Management, 27(8), 846-873.

Grigoroudis, E., Orfanoudaki, E. \& Zopounidis, C. (2012). Strategic performance measurement in a healthcare organisation: A multiple criteria approach based on balanced scorecard. Omega, 40(1), 104-119.

Johnsen, A. (2015). Strategic management thinking and practice in the public sector: A strategic planning for all seasons? Financial Accountability and Management, 31(3), 243268.

Kaplan, R. S. \& Bower, M. (1999). The Balanced scorecard for public sector organizations. Boston: Harvard Business School.

Kaplan, R. S. \& Norton, D. P. (2000). Having trouble with your strategy? Then map it. Harvard Business Review, 49(1), 167-176.

Kaplan, R. S. \& Norton, D. P. (1996). Linking the balanced scorecard to strategy. California Management Review, 39(1), 53-79.

Kaplan, R. S. \& Norton, D. P. (2004). Organizações do setor público. In: Mapas estratégicos: como converter ativos intangíveis em resultados tangíveis. Rio de Janeiro: Elsevier.

Kaplan, R. S. \& Norton, D. P. (1992). The Balanced scorecard: measures that drive performance. Harvard Business Review, 70(1), 71-79.

Kayuni, H. M. (2017). Strategic Planning in the Malawi Public Sector: Potential Tool for Progress or Regression? Public Organization Review, 17(3), 373-391.

Lück, H. (2009). Dimensões de gestão escolar e suas competências. Positivo.

Lunenburg, F. (2010). The Principal and the school: what do principals do. National Forum of Educational Administration and Supervision Journal, 27(4), 1-13.

Marr, B., Schiuma, G. \& Neely, A. (2004). The Dynamics of value creation: mapping your intellectual performance drivers. Journal of Intellectual Capital, 5(2), 312-325.

Maccarrone, V., Filiciotto, F., Buffa, G., Mazzola, S. \& Buscaino, G. (2014). The ICZM balanced scorecard: A tool for putting integrated coastal zone management into action, Marine Policy, 44(1), 321-334.

Malhotra, N. K. (2012). Pesquisa de marketing: uma orientação aplicada. Porto Alegre: Bookman.

Mawela, T., Twinomurinzi, H. \& Ochara, N. M. (2017). Exploring public sector planning for transformational government. Journal of Science and Technology Policy Management, 8(3), 352-374. 
McAdam, R., Hazlett, S. A. \& Casey, C. (2005). Performance management in the UK public sector. International Journal of Public Sector Management, 18(3), 256273.

Mcmahon, L. \& Phillimore, J. (2013). State and Territory Government Strategic Plans: Exercises in Managing, Monitoring and Marketing. Australian Journal of Public Administration, 72(4), 404-418.

Mintzberg, H. (1994). The Fall and rise of strategic planning. Harvard Business Review, 72(1), 107-114.

Mintzberg, H., Lampel, J. \& Ahlstrand, B. (1999). Todas as partes do elefante. HSM management, 2(12), 100-101.

Mizrahi, S. E., \& Canen, A. G. (2012). Gestão estratégica multicultural baseada no Balanced Scorecard em instituições de ensino. Ensaio: Avaliação e Políticas Públicas em Educação, 20(74), 27-49.

Moore, M. H. (2002). Criando Valor Público: Gestão Estratégica no Governo. Rio de Janeiro: Uniletras.

Najgebauer, A., Antkiewicz, R., Pierzchała, D. \& Rulka, J. (2017). Quantitative Methods of Strategic Planning Support: Defending the Front Line in Europe. Advances in Intelligent Systems and Computing, 656(1), 290-299.

Cabral Neto, A. \& Castro, A. M. D. A. (2011). Gestão escolar em instituições de ensino médio: entre a gestão democrática e a gerencial. Educação e Sociedade, 32(116), 745-770.

Neuendorf, K. A. (2002). The Content Analysis Guidebook. Thousand Oaks: Sage.

Norreklit, H. (2000). The Balance on balanced scorecard - a critical analysis of some of its assumptions. Management Acoounting Research, 11 (1), 65-88.

Northcott, D. \& Taulapapa, T. M. (2012). Using the balanced scorecard to manage performance in public sector organizations. International Journal of Public Sector Management, 25(3), 166-191.

Oloruntoba, R. (2013). Plans never go according to plan: An empirical analysis of challenges to plans during the 2009 Victoria bushfires. Technological Forecasting and Social Change, 80(9), 1674-1702. \& Sons.

Olsen, E. (2012). Strategic Planning Kit for Dummies. New Jersey: John Wiley

Paro, H. (2010). A Educação, a política e a administração: reflexões sobre a prática do diretor escolar. Educação e Pesquisa, 36(3), 763-778.

Pasha, O. \& Poister, T. H. (2017). Exploring the Change in Strategy Formulation and Performance Measurement Practices Under Turbulence. Public Performance and Management Review, 40(3), 504-528.

Plaček, M., Půček, M. J. \& Šilhánková, V. (2017). New trends in the strategic management of museums in the Czech Republic. Museum Management and Curatorship, 32(4), 302-318. 
Poister, T. H. (2010). The future of strategic planning in the public sector: Linking strategic management and performance. Public Administration Review, 70(SUPPL. 1), p. 246-254.

Purnawan \& Sanjaya, F. (2017). Important performance analysis as a strategic planning technique in bus rapid transit development program. International Journal of Civil Engineering and Technology, 8(10), 805-813.

Queiroz, R. T. \& Lobosco, A. (2015). A Inserção da Ferramenta Balanced Scorecard no Planejamento Estratégico de uma Empresa em Crescimento: Um Estudo de Caso na Empresa Metadil Indústria e Comércio Metalúrgica Ltda. Future Studies Research Journal, $7(1), 81-112$.

Quesado, P. R., Rodrigues, L. L. \& Guzmán, B. A. (2012). O tableau de bord e o balanced scorecard: uma análise comparativa. Revista Contabilidade e Controladoria, 4(2), 128-150.

Quezada, L. E., Cordova, F. M., Palominos, P., Godoy, K. \& Ross, J. (2009). Method for identifying strategic objectives in strategy maps. International Journal of Production Economics, 122(1), 492-500.

Rahiminia, F. \& Karzogar, N. (2016). Objectives priority in university strategy map for resource allocation, Benchmarking, 23(2), 371-387.

Rinaldi, F. M. (2016). From local development policies to strategic planningAssessing continuity in institutional coalitions. Evaluation and Program Planning, 56(1), 76-87.

Ringma, J. L, Wintle, B., Fuller, R. A., Fisher, D. \& Bode, M. (2017). Minimizing species extinctions through strategic planning for conservation fencing. Conservation Biology, 31(5), 1029-1038.

Schobel, K. \& Scholey, C. (2012). Balanced scorecards in education: focusing on financial strategies. Measuring Business Excellence, 16(3), 17-28.

Silva, E. L. \& Menezes, E. M. (2005). Metodologia da pesquisa e elaboração de dissertação. Florianópolis: UFSC.

Souza, R. G. \& Cordeiro, J. S. (2010). Mapeamento cognitivo e balanced scorecard na gestão estratégica de resíduos sólidos urbanos, Gestão \& Produção, 17(3), 483-496.

Staples, W. \& Dalrymple, J. (2016). Construction Procurement and State Government Strategy: Aligned or Disconnected? Australian Journal of Public Administration, 75(2), 222235.

Sutheewasinnon, P., Hoque, Z. \& Nyamori, R. O. (2016). Development of a performance management system in the Thailand public sector: Isomorphism and the role and strategies of institutional entrepreneurs. Critical Perspectives on Accounting, 40(1), 26-44.

Thompson Jr., A. \& Strickland III, A. J. (2000). Planejamento estratégico elaboração, implementação e execução. São Paulo: Pioneira.

Wolf, C. \& Floyd, S. W. (2017). Strategic Planning Research: Toward a Theory-Driven Agenda. Journal of Management, 43(6), 1754-1788. 
Younis, R. \& Knight, M. A. (2014). Development and implementation of an asset management framework for wastewater collection networks, Tunneling and Underground Space. Technology, 39(1), 130-143.

Yuen, P. P. \& Ng, A. W. (2012). Towards a balanced performance measurement system in a public health care organization. International Journal of Health Care Quality Assurance, 25, 421-430. 